\title{
The antimicrobial effect of fresh garlic and garlic oil supplemented with ground beef
}

\author{
Mahmoud Ahmed Mahros*1, Asmaa Reda Eltanahy ${ }^{2}$, Samir Mohammed Abd-Elghany ${ }^{1}$, Khalid Ibrahim \\ Sallam ${ }^{1}$
}

${ }^{1}$ Food Hygiene and Control Department, Faculty of Veterinary Medicine, Mansoura University, Mansoura 35516, Egypt.

${ }^{2}$ General Veterinary Authority, Mansoura Branch, Egypt.

\section{ARTICLE HISTORY ABSTRACT}

Received: 23.01.2021

Revised: 11.03 .2021

Accepted: 16.03 .2021

Correspondence to Mahmoud A. Mahros *; Tel. +201033016603; E-mail: mahmoudmahros@yahoo.com; ORCID: 0000-0003-3423-0085

\begin{abstract}
Objective: The study was designed to investigate the antibacterial effect of fresh garlic and garlic oil against the aerobic bacteria in beef meatballs during their cold storage at $4^{\circ} \mathrm{C}$.

Design: Observational study

Procedures: Three concentrations of fresh garlic (FG) (2\%, 3\%, and 5\%) and garlic oil (GO) (250 mg/kg, $360 \mathrm{mg} / \mathrm{kg}$, and $600 \mathrm{mg} / \mathrm{g}$ ) were added to ground beef samples then treated meat and untreated (control) were kept in refrigeration at $4{ }^{\circ} \mathrm{C}$ for 15 days and their aerobic bacteria were determined.

Results: The addition of garlic to ground beef significantly reduced (more than $3 \log _{10} \mathrm{CFU} / \mathrm{g}$ ) their aerobic bacteria during their refrigerated storage, in comparison with untreated meat. Furthermore, FG achieved a maximal reduction than GO, however, FG $5 \%$ and GO $600 \mathrm{mg} / \mathrm{kg}$ showed the most potent antibacterial effect. The sensory evaluation of treated meat revealed that FG $5 \%$ and $\mathrm{GO} 600 \mathrm{mg} / \mathrm{kg}$ had a significant strongest garlic flavor and the least acceptable score than other meat investigated.

Conclusion and clinical relevance: The results indicated that garlic added to ground beef tested exhibited obvious effect against aerobic bacteria and can be used as a useful preservative in meat products.
\end{abstract}

Keywords: Garlic; Antimicrobial effect; Aerobic bacteria; Beef; Refrigerated storage.

\section{INTRODUCTION}

Ground beef is a popular food item used in various dishes in Egypt and all over the world. However, this meat can be easily contaminated with microorganisms because of process contaminations, improper handling, and preservation which support the growth of both spoilage and pathogenic bacteria resulted in loss of their quality (food spoilage) and constitute potential health problems (food poisoning) [1].

Therefore, consumer concerns on the safety of foods containing chemicals preservatives resulted in a growing need for the use of natural preservatives like spices especially those having characteristic flavor, antioxidant, and/or antimicrobial activities [2]. From these spices, garlic (Allium sativum) and its extracts have been used for many centuries by various cultures in food preservation and in the treatment of infectious diseases [3]. In this regard, garlic is rich in selenium and organosulfur compounds that established and pronounced antioxidant activity [4]. Furthermore, garlic has broad spectrum antimicrobials as it has antibacterial, antifungal, antiviral, and antiprotozoal activities [5].

The main antimicrobial activity of garlic is mainly attributed to its organosulfur compounds referred as allicin (diallyl disulphide and diallyl trisulphide). However, intact garlic bulbs do not contain allicin in its active form, but contain its precursor, alliin (S-allyl-L-cysteine sulphoxide) [6]. Garlic extracts exhibited antibacterial activity against both Gram-negative bacteria as Pseudomonas spp., E. coli, Salmonella spp., Citrobacter spp., Enterobacter spp.,
Klebsiella spp., and Helicobacter pylori and Gram-positive bacteria as S. aureus, S. pneumoniae, Group A Streptococcus spp., Bacillus anthracis, Clostridium botulinum, and Mycobacterium spp. [7-9].

Owing to the widespread consumption of ground beef especially in restaurants which commonly use it after mixing with various spices and subsequent storage which may reach to several days, this study designed to evaluate the antibacterial effect of garlic on aerobic bacteria mostly contaminate this meat and resulted in spoilage of it.

\section{MATERIALS AND METHODS}

\subsection{Collection and preparation of ground beef and garlic}

A total of $6.300 \mathrm{~kg}$ of fresh beef were purchased from different butchers' shops in Mansoura city. Under complete aseptic conditions, the meat was minced then divided into two parts; $2.100 \mathrm{~kg}$ was used for studying the antibacterial effect of both fresh garlic (FG) and garlic oil (GO) on the aerobic plate counts contaminating the meat tested; the other $4.200 \mathrm{~kg}$ was separately used for sensory evaluation of meat supplemented with garlic.

For bacteriological investigations, the $2.100 \mathrm{~kg}$ was divided into seven groups: one control group (ground beef without addition of garlic) and six treated groups with fresh garlic $(2 \%, 3 \%$, and $5 \%, w / w)$, and garlic oil $(250 \mathrm{mg} / \mathrm{kg}, 360$ $\mathrm{mg} / \mathrm{kg}$, and $600 \mathrm{mg} / \mathrm{kg}, \mathrm{v} / \mathrm{w})$. 
Fresh garlic was obtained from a local market in Mansoura city, while GO was purchased from Amazon, USA. Both of fresh garlic and garlic oil were added to the ground meat surface and distributed by hands (with sterile gloves). After that, meat samples were packed individually, in polyethylene bags and kept in refrigeration storage at $4{ }^{\circ} \mathrm{C}$, and investigated in the $0,3,6,9,12$, and 15 , days of storage.

\subsection{Bacteriological analyses}

For determination of the antibacterial effect of garlic, the total aerobic plate counts (APCs) for all treated meat together with the control ones were determined. Briefly, $10 \mathrm{gm}$ of each meat sample were homogenized in $0.1 \%$ sterile peptone water (Oxoid CM0009) and serial dilutions were performed according to the method described by ISO (2003) [10]. From the prepared serial dilutions, appropriate dilutions were duplicate plated on plate count agar (Oxoid CM0325) and incubated at $30^{\circ} \mathrm{C}$ for 2 days [11]. Then, the bacterial colonies in countable plates were counted for all treated samples in addition to the control sample and the total APCs per each gram were determined.

\subsection{Sensory evaluation}

The sensory evaluation of cooked meatballs (20 gm each) was carried out by 10 trained panelists of staff according to method described by Sallam et al. [12]. Meatballs were cooked for $15 \mathrm{~min}$ in conventional microwave oven (Sharp electronics, Japan) adjusted at $180^{\circ} \mathrm{C}$. Individual presentation of representative seven meatball samples (control and treated meat) were done in covered porcelain dishes to each panelist who asked to evaluate them blindly. Panelists were instructed to eat cooked meatballs and drink water for cleansing palate with 30 second between samples. Then, evaluation was done by panelists for the overall acceptability regarding intensity and tenderness. A nine-point hedonic scoring scale was carried out for flavor intensity, tenderness of meat, Juiciness, and evaluation of the overall acceptability, respectively as follow: $(9=$ extremely intense/tender/like, $8=$ very intense/tender/like, $7=$ moderately intense/tender/like, 6=slightly intense/tender/like, 5= barely intense/tender/like, $4=$ slightly bland/tough/dislike, 3= moderately bland/tough/dislike, $2=$ very bland/tough/dislike, 1= extremely bland/tough/dislike). Meatball samples receive overall scores of more than 4 were considered Acceptable, while they were considered borderline of acceptability when the score is between 3 and 4 , and samples gained scores below 3 were unacceptable.

\subsection{Statistical analysis}

All meat samples were analyzed on $0,3^{\text {rd }}, 6^{\text {th }}, 9^{\text {th }}, 12^{\text {th }}$, and $15^{\text {th }}$ days of refrigerated storage. All measurements were carried out in triplicate and data were statistically analyzed through analysis of variance (ANOVA) using SPSS program software [13]. The differences between means were determined by the least significant difference test, and significance was defined at $P<0.05$.

\section{RESULTS}

Table 1. Effect fresh garlic (FG) and garlic oil (GO) supplemented with ground beef on their aerobic plate counts $\left(\log _{10} \mathrm{CFU} / \mathrm{g}\right)$ during the cold storage at $4{ }^{\circ} \mathrm{C}$ for 15 days.

\begin{tabular}{llllllll}
$\begin{array}{l}\text { Day of } \\
\text { storage }\end{array}$ & Control & $\begin{array}{l}\text { FG } \\
2 \%\end{array}$ & FG 3\% & $\begin{array}{l}\text { FG } \\
5 \%\end{array}$ & $\begin{array}{l}\text { GO } \\
250 \\
\mathrm{mg} / \mathrm{kg}\end{array}$ & $\begin{array}{l}\mathrm{GO} \\
360 \\
\mathrm{mg} / \mathrm{kg}\end{array}$ & $\begin{array}{l}\mathrm{GO} \\
600 \\
\mathrm{mg} / \mathrm{kg}\end{array}$ \\
\hline $\mathbf{0}$ & $4.9^{\mathrm{A}}$ & $4.5^{\mathrm{AB}}$ & $4.3^{\mathrm{B}}$ & $4^{\mathrm{C}}$ & $4.6^{\mathrm{AB}}$ & $4.3^{\mathrm{B}}$ & $4.4^{\mathrm{B}}$ \\
$\mathbf{3}$ & $6^{\mathrm{A}}$ & $5.1^{\mathrm{B}}$ & $4.7^{\mathrm{C}}$ & $4.1^{\mathrm{C}}$ & $5.1^{\mathrm{B}}$ & $4.8^{\mathrm{C}}$ & $4.8^{\mathrm{C}}$ \\
$\mathbf{6}$ & $6.9^{\mathrm{A}}$ & $5.5^{\mathrm{B}}$ & $5.1^{\mathrm{C}}$ & $4.0^{\mathrm{D}}$ & $5.8^{\mathrm{B}}$ & $5.2^{\mathrm{C}}$ & $5.2^{\mathrm{C}}$ \\
$\mathbf{9}$ & $8.3^{\mathrm{A}}$ & $6^{\mathrm{C}}$ & $6.1^{\mathrm{C}}$ & $4.8^{\mathrm{D}}$ & $6.5^{\mathrm{B}}$ & $6.1^{\mathrm{C}}$ & $5.8^{\mathrm{C}}$ \\
$\mathbf{1 2}$ & $9.6^{\mathrm{A}}$ & $6.3^{\mathrm{C}}$ & $6.2^{\mathrm{C}}$ & $5.4^{\mathrm{D}}$ & $7.1^{\mathrm{B}}$ & $6.8^{\mathrm{BC}}$ & $6.2^{\mathrm{C}}$ \\
$\mathbf{1 5}$ & $10.9^{\mathrm{A}}$ & $6.7^{\mathrm{C}}$ & $6.4^{\mathrm{C}}$ & $5.7^{\mathrm{D}}$ & $7.6^{\mathrm{B}}$ & $7.2^{\mathrm{BC}}$ & $6.8^{\mathrm{C}}$ \\
& & & & & & & \\
\end{tabular}

$A-D=$ Means with different letters in the same row are significantly different at $\mathrm{P}<0.05$.

Table 2. Sensory characteristics of cooked meatballs supplemented with fresh garlic (FG) and garlic oil (GO).

\begin{tabular}{|c|c|c|c|c|}
\hline \multirow{2}{*}{$\begin{array}{l}\text { Investigated } \\
\text { meat }\end{array}$} & \multicolumn{4}{|c|}{ Sensory characteristics* } \\
\hline & Flavor & Tenderness & Juiciness & $\begin{array}{l}\text { Overall } \\
\text { acceptability }\end{array}$ \\
\hline Control & $4^{c}$ & $7^{A B}$ & $8^{A}$ & $4^{\mathrm{D}}$ \\
\hline FG $2 \%$ & $6^{\mathrm{B}}$ & $7^{A B}$ & $8^{A}$ & $8^{A}$ \\
\hline FG $3 \%$ & $7^{A}$ & $6^{\mathrm{B}}$ & $8^{A}$ & $7^{A B}$ \\
\hline FG $5 \%$ & $8^{A}$ & $6^{\mathrm{B}}$ & $7^{A}$ & $6^{\mathrm{BC}}$ \\
\hline GO $250 \mathrm{mg} / \mathrm{kg}$ & $6^{\mathrm{B}}$ & $8^{A}$ & $8^{A}$ & $8^{A}$ \\
\hline GO $360 \mathrm{mg} / \mathrm{kg}$ & $7^{A B}$ & $7^{\mathrm{AB}}$ & $7^{A}$ & $6^{\mathrm{BC}}$ \\
\hline GO 600 mg/kg & $8^{A}$ & $7^{A B}$ & $7^{A}$ & $5^{\mathrm{CD}}$ \\
\hline \multicolumn{5}{|c|}{$\begin{array}{l}A-D=\text { Means with different letters in the same row are significantly different } \\
\text { at } P<0.05 \text {. }\end{array}$} \\
\hline \multicolumn{5}{|c|}{$\begin{array}{l}\text { *A nine-point hedonic scoring scale for flavor intensity, tenderness, and } \\
\text { juiciness of meat as follow: } 9 \text { : extremely intense/tender/Juicy; } 8 \text { : very } \\
\text { intense/tender/Juicy; } 7 \text { : moderately intense/tender/Juicy; } 6 \text { : slightly } \\
\text { intense/tender/Juicy; } 5 \text { : barely detected flavor/tender/juicy; } 4 \text { : slightly } \\
\text { bland flavor/tender/juicy; 3: moderately bland/tender/juicy; } 2 \text { : very bland } \\
\text { flavor/tender/juicy; } 1 \text { : extremely bland flavor/tender/juicy beside the } \\
\text { overall acceptability, respectively. }\end{array}$} \\
\hline
\end{tabular}

\section{DISCUSSION}

For centuries, garlic has been used to combat infectious diseases in various societies, and it has been proven to be effective against various Gram-positive and Gram-negative bacteria as Salmonella, E. coli and potentially harmful enterobacteria [7-9]. The antibacterial activity and beneficial components of garlic is due to its content of organosulpher compounds with allicin, other thiosulfinates, and their transformation products having antimicrobial activity of garlic which are inhibitory to food spoilage bacteria [6].

Data in Table (1) revealed that addition of both FG and $\mathrm{GO}$ to ground beef induced a significant reduction in their aerobic bacteria all over the refrigerated storage time (at $4{ }^{\circ} \mathrm{C}$ for 15 days), however APCs increased in all meats investigated, the APCs in treated meats were more than 3 $\log _{10} \mathrm{CFU} / \mathrm{g}$ lower than those in control (untreated meats) (Table 1 \& Figures 1 \& 2). In untreated meat (control), the initial APCs (4.9 $\log _{10}$ CFU/g) rapidly increased all over the storage time and reached $10.9 \log _{10} \mathrm{CFU} / \mathrm{g}$ in the $15^{\text {th }}$ day of storage. On the other hand, the APCs in treated meat (with FG $2 \%, 3 \%$, and $5 \%$ and GO $250 \mathrm{mg} / \mathrm{kg}, 360 \mathrm{mg} / \mathrm{kg}$, and 600 $\mathrm{mg} / \mathrm{kg}$ ) were reduced and reach to $7.6 \log _{10} \mathrm{CFU} / \mathrm{g}$ at the end of storage time (15 days) (Table 1 \& Figures $1 \& 2$ ). It was 
noticed that no deterioration observed in treated meat till the end of storage (15 days), whereas deterioration of untreated meat started at the $8^{\text {th }}$ day of storage.

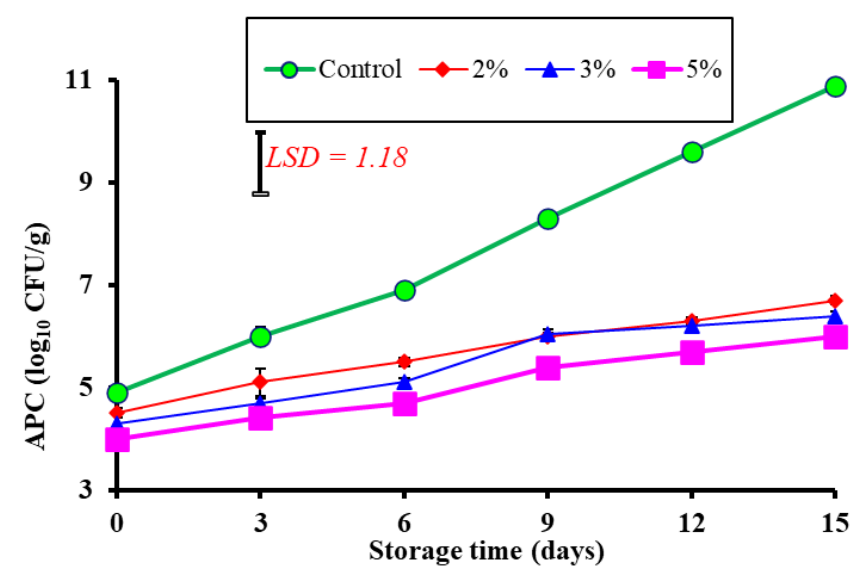

Figure 1. Variation of aerobic plate counts $\left(\log _{10} \mathrm{CFU} / \mathrm{g}\right)$ in ground beef supplemented with fresh garlic (FG) during the cold storage at $4{ }^{\circ} \mathrm{C}$ for 15 days.

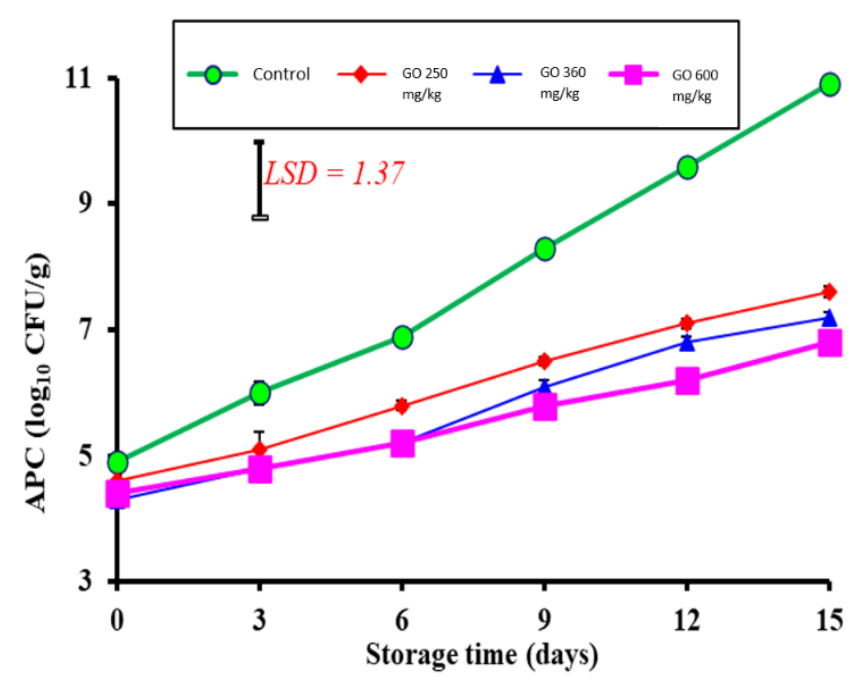

Figure 2. Variation of aerobic plate counts ( $\left.\log _{10} \mathrm{CFU} / \mathrm{g}\right)$ in ground beef supplemented with garlic oil (GO) during the cold storage at $4{ }^{\circ} \mathrm{C}$ for 15 days.

Regarding the antibacterial effect of garlic based on the results obtained, meat supplemented with FG were lower in their APCs than that treated with GO (Table 1). In this context, FG $5 \%$ treated meat had the lowest values of APC when compared to other treatment or control (Table 1 \& Figure 1). Furthermore, GO $600 \mathrm{mg} / \mathrm{kg}$ treated meat showed the lowest APC than GO $250 \mathrm{mg} / \mathrm{kg}$ or GO $360 \mathrm{mg} / \mathrm{kg}$ or control ones (Table 1 \& Figure 2). These results were agreed with those previously reported [14 \&15]. Similarly, Sallam et al. [12] mentioned that addition of FG $(30 \mathrm{~g} / \mathrm{kg})$ or garlic powder ( 9 $\mathrm{g} / \mathrm{kg}$ ) to chicken sausage significantly reduced their APCs and subsequently extended their shelf-life to 21 days. In the same context, Salem et al. [16] reported that treatment of ground beef samples with $\mathrm{GO}$ had an effectiveness in decreasing their APCs and GO $600 \mathrm{mg} / \mathrm{kg}$ induced the highest reduction levels and the shelf life of treated samples was extended 6 days more than untreated samples. On the contrary, Sun et al. [17] and Gheisari and Ranjbar [18] mentioned that garlic did not produce significant differences in APCs when added to heat dried Chinese style sausage and cold stored ground camel meat, respectively. In ground beef supplemented with garlic, the reduction of APCs, in comparison with control samples, may be attributed to the organosulfur compounds and their precursor's allicin in garlic [6].

Regarding the sensory characteristics of ground beef treated with garlic, the intensity of garlic flavor, tenderness, juiciness, and overall acceptability (pooled data over the storage time up to 15 days) are affected by different equivalent concentrations of fresh garlic and garlic oil are presented in Table (2). Meatballs supplemented with all garlic formulation (fresh garlic and garlic oil) had the more garlic flavor than the control. FG 5\% had the highest score and had a significant $(P<0.05)$ stronger flavor than the control flavor. Moreover, GO $250 \mathrm{mg} / \mathrm{kg}$ showed the highest score for tenderness, while FG $3 \%$ and $5 \%$ had the lowest score for tenderness. All meatballs supplemented with garlic formulation showed high score for tenderness than the control sample. In addition, GO $250 \mathrm{mg} / \mathrm{kg}$ had the highest score for tenderness. However, FG 3\% and 5\% showed lowest score for tenderness (Table 2). Additionally, FG 2\% and GO $250 \mathrm{mg} / \mathrm{kg}$ had the highest degree of acceptability and FC 5\% and GO $600 \mathrm{mg} / \mathrm{kg}$ had a significant $(\mathrm{P}<0.05)$ strongest garlic flavor and the least acceptable score. The intensity of garlic flavor, tenderness and enhanced overall acceptability of ground meat treated with GO were similarly reported, worldwide $[12 ; 17 ; 19 \& 20]$. Moreover, the acceptability of the taste of highly spiced food is transmitted both culturally and genetically, and the countries with hotter climates used spices more frequently and at much higher levels than countries with cooler climates [21].

\section{CONCLUSION}

This study concluded that Addition of garlic to ground beef reduced their aerobic bacteria and increased their shelf life in refrigerated storage (at $4{ }^{\circ} \mathrm{C}$ for 15 days). However, a high concentration may not be accepted by many people due to its strong flavor. Additionally, FG had the best effect in comparison with GO and FG $5 \%$ and GO $600 \mathrm{mg} / \mathrm{kg}$ showed the most potent effect. Therefore, garlic may be supplemented with meat products, as a natural herb, to lower their aerobic bacteria and extend the shelf-life instead of some chemical preservatives.

\section{Conflict of interest statement}

No conflict of interest.

\section{Research Ethics Committee permission}

The research was conducted according to standards of Research Ethics Committee, Faculty of Veterinary Medicine, Mansoura University.

\section{Authors' contribution}

Mahros A. M. supervised the practical part, drafted, and revised the manuscript. Eltanahy $A$. R. collected the samples carried out the practical part. Abd-Elghany S. M. supervised the practical work and revised the manuscript. Sallam K. I. 
designed the experiment, supervised the practical work, and revised the manuscript.

\section{REFERENCES}

[1] Vemozy-Rozand C, Ray-Gueniot S, Ragot C. Bavai C, Mazuy C,Montet M.P. Prevalence of Escherichia coli 0157:H7 in industrial minced beef. Lett Appl Microbiol 2002;35:7-11. https://doi.org/10.1046/j.1472765X.2002.01116.x

[2] Ranjan S, Dasgupta N, Saha P, Rakshit M, Ramalingam C. Comparative study of antibacterial activity of garlic and cinnamon at different temperature and its application on preservation of fish. Adv Appl Sci Res 2012;3(1):495-501.

[3] Kumar L. Influence of different levels of nitrogen and spacing on growth, yield and quality of garlic (Allium sativum L.) cv. G-1. Indian J Pure Appl Biosci 2020;8(4):209-14. https://doi.org/10.18782/2582-2845.8225

[4] Yin M, Hwang S, Chan K. Nonenzymatic antioxidant activity of four organosulfur compounds derived from garlic. J Agri Food Chem 2002;50:6143-7. https://doi.org/10.1021/jf0204203

[5] Harris JC, Cottrell SL, Plummer S, Lloyd D. Antimicrobial properties of Allium sativum (garlic). Appl Microbiol Biotechnol 2001;57:282-6. https://doi.org/10.1007/s002530100722

[6] Kyung KH. Antimicrobial properties of allium species. Curr opin biotechnol 2012;23(2):142-7. https://doi.org/10.1016/j.copbio.2011.08.004

[7] Mukhtar S, Ghori I. Antibacterial activity of aqueous and ethanolic extracts of garlic, cinnamon and turmeric against Escherichia coli ATCC 25922 and Bacillus subtilis DSM 3256. Int J Appl Biol Pharma Technol 2012;3(2):131-6.

[8] Casella S, Leonardi M, Melai B, Fratini F, Pistelli L. The role of diallyl sulfides and dipropyl sulfides in the in vitro antimicrobial activity of the essential oil of garlic, Allium sativum L., and Leek, Allium porrum L. Phytother Res 2012;27(3):380-3. https://doi.org/10.1002/ptr.4725

[9] Muhammad G, Muammad I, Sobia K, Dawood A, Muhammad JA, Kashis SA, et al. A comparative study of antimicrobial and antioxidant activities of garlic (Allium sativum L.) extracts in various localities of Pakistan. Afr J Plant Sci 2014;8(6):298-306.

[10] ISO. ISO. 2003. No. 6887. Microbiology of food and animal feeding stuffs - Preparation of test samples, initial suspension and decimal dilutions for microbiological examination -- Part 2: Specific rules for the preparation of meat and meat products. ISO (2003). Geneva, Switzerland.

[11] ISO. ISO 4833-2:2013. Microbiology of the food chain - horizontal method for the enumeration of microorganisms - Part 2: Colony count at $30{ }^{\circ} \mathrm{C}$ by the surface plating technique. ISO (2013) Geneva, Switzerland.

[12] Sallam KI, Ishioroshi M, Samejima K. Antioxidant and antimicrobial effects of garlic in chicken sausage. LWT - Food Sci Technol 2004;37(8):849-55. https://doi.org/10.1016/j.lwt.2004.04.001

[13] SPSS. Statistical package for social science release 16-0 version.2004; SPSS Incompany. USA.

[14] Kalkan S, Taş E, Erginkaya Z, Turhan EÜ. Determination of antimicrobial effects of probiotic lactic acid bacteria and garlic extract against some foodborn pathogenic bacteria. Turkish J Agri - Food Sci Technol 2017;5(2):125. https://doi.org/10.24925/turjaf.v5i2.125-131.965

[15] El-Khateib T, Abd El-Rahman HA. Effect of garlic and Lactobacillus plantarum on growth of Salmonella typhimurium in Egyptian fresh sausage and beefburger. J Food Prot 1987;50(4):310-11. https://doi.org/10.4315/0362-028X-50.4.310

[16] Salem AM, Amin RA, Afifi GS. (2010): Studies on antimicrobial and antioxidant efficiency of some essential oils in minced beef. J Amer Sci 2010;6(12):691-202.

[17] Sun YM, Ockerman HW, Marriott NG. Garlic in chinese sausage. J Muscle Foods 2000;11(1):35-43. https://doi.org/10.1111/j.17454573.2000.tb00413.x

[18] Gheisari HR, Ranjbar VR. Antioxidative and antimicrobial effects of garlic in ground camel meat. Turk. J. Vet. Anim. Sci. 2012; 36(1):13-20.

[19] Ankri S, Mirelman D. Antimicrobial properties of allicin from garlic. Microbes Infect 1999;1:125-129. https://doi.org/10.1016/S12864579(99)80003-3

[20] Javed MS, Khan MI, Randhawa MA, Sajid MW, Khan AA, Nasir MA. Garlic (Allium Sativum L.) as an antimicrobial and antioxidant agents in beef sausages. Pak J Food Sci 2011;21:22-32.
[21] Mozaffari Nejad A. S., Shabani S., Bayat M. and Hosseini S. E. (2014): Antibacterial Effect of Garlic Aqueous Extract on Staphylococcus aureus in Hamburger. Jundishapur J Microbiol 2014;7(11):1-5. https://doi.org/10.5812/jjm.13134 